\title{
MEMBINGKAI KEPRIBADIAN ULUL ALBAB GENERASI MILENIAL
}

\author{
Misbahul Munir \\ Dosen STAI Ma'had Aly Al-Hikam Malang \\ munirmisbahul1990@gmail.co.id
}

\begin{abstract}
Abstrak
Problematika kepribadian yang dihadapi generasi millenial saat ini sangat memprihatinkan, diantaranya adalah persoalan adiksi gadget, tidak fokus pada belajar, emosinya mudah terganggu, pornografi, pergaulan bebas. Sebagai tawaran solusi adalah internalisasi nilai kepribian ulul albab, yaitu melalui pengamalan dzikir, fikir, amal soleh. Internealisasi kepribadian ulul albab memungkinkan bisa mengatasi krisis moral yang sedang terjadi saat ini. Keunikan yang dimiliki generasi millenial ulul albab ialah terampil dalam mengakses teknologi digital, sekaligus mempunyai prinsip nilai agama yang kokoh.
\end{abstract}

Keywords; generasi millenial, kepribadian ulul albab

\section{Pendahuluan}

Adalah sebuah keniscayaan peradaban manusia terus berkembang. Perkembangan peradaban manusia mulai ditandai dari peradaban pertanian, industri, dan pada saat ini teknologi informasi komunikasi digital yang mengandalkan perangkat internet. Bisa dikatakan teknologi digital tidak dapat dilepaskan dalam setiap aktivitas manusia. Meninjam istilah Zuhal dan Naisbitt, ${ }^{1}$ high teknologi menjadi bagian penting dalam kehidupan generasi yang hidup saat ini.

Salah satu identitas dimulainya babak baru peradaban manusia, ialah sejak menjadikan sarana teknologi informasi komunikasi digital sebagai sesuatu kebutuhan yang selalu mendampingi setiap aktifitas manusia. Babak baru ini ditandai sebagai munculnya generasi milenial, yakni generasi yang melihat cara pandang internet sebagai temuan yang bisa mengubah segalanya. Sarana akses informasi bisa diperoleh tanpa batas, komunikasi

${ }^{1}$ John Naisbitt, Et. All. High Tech High Touch (Jakarta: Pustaka Mizan, 2002). Lihat juga Zuhal, Visi Iptek Memasuki Milenium III (Jakarta: Universitas Pendidikan Indonesi Pers, 2000). 
juga tidak harus dilakukan secara tatap muka langsung, semua orang dapat mempelajari dan membagikan keilmuan dengan mudah tanpa bertatap muka secara langsung.

Perubahan antar cara pandang inilah yang menjadikan generasi millenial sudah jauh berubah dari generasi sebelumnya. Generasi millenial memiliki kekhasan yang berbeda dalam memahami realitas kehidupan. Secara kelebihan generasi ini lebih mengerti teknologi, mudah mengakses banyak perkembangan isu yang terjadi dimasyarakat, mengakses banyak informasi yang menunjang sumber petengahuan secara mudah melalui akses internet.

Kemudahan mengakses teknologi komunikasi dan informasi digital yang tanpa batas bukan berarti menjadi kelebihan secara mutlak, dilain sisi menjadi problem yang bisa memunculkan degradasi moral seperti saat ini yang sudah sangat memprihatinkan. Antara lain ditandai dengan kebebasan bergaul antar jenis sudah menjadi bias, sebagai akibat dari perkembangan teknologi yang tidak diimbangi peningkatan kualitas moral. Artinya perkembangan teknologi secara pesat, harus diimbangi dengan kualitas kepribadian yang unggul dari nilai-nillai agama. Tidak menafikkan diri, bahwa perkembangan teknologi sangat dibutuhkan oleh bangsa dalam era persangain global seperti saat ini, pemahaman agama yang kokoh jauh lebih penting sebagai filtrasi mencegah suatu hal yang negatif.

Jika memperhatikan jumlah populasi manusia Indonesia yang tergolong generasi milenial terbilang cukup besar. 15 hingga 20 tahun yang akan datang wajah Indonesia adalah generasi millenial saat ini. Bonus demografi generasi millenial ada sekitar 34,45\% memiliki rentang usia 15-34 tahun. ${ }^{2}$ Ini akan menjadi bom waktu jika tidak dirawat dengan penanaman nilai kepribadian religius, yaitu kepribadian yang didasarkan pada nilai-nilai keagamaan. Pada pengkajian ini penulis membatasi dari perspektif Islam.

Dari penjelasan diatas, artikel ini mengajak pembaca untuk mengetahui peran agama dalam internalisasi nilai kepribadian. Secara spesifik penulis batasi pada nilai kepribadian Islam ulul albab generasi milenial. Isi dari pembahasan adalah untuk mengetahui; apa yang dimaksud karakter ulul albab, bagaimana telaah terkait periodesasi generasi dan bagaimana problematika karakter generasi millenial, bagaimana bingkai internalisasi nilai ulul albab pada generasi millenial.

\footnotetext{
${ }^{2}$ Hasanudin Ali, “Generasi Millennial Indonesia: Tantangan dan Peluang Pemuda Indonesia”, http://alvara-strategic.com, pada tanggal 30 desember 2017 jam 07.00.
} 


\section{Kepribadian Ulul Albab}

Kepribadian merupakan ciri yang dimiliki manusia atau keunikan yang dimiliki manusia, yang membuat dirinya berbeda dengan satu sama lainnya secara psikis. Keunikan secara psikis ini bisa jadi mampu bertahan lama, bisa juga bersifat sementara berubah sesuai dengan situasi yang ada. ${ }^{3}$ Sedangkan dalam Islam pembahasan kepribadian diartikan sebagai akhlaq, istilah akhlaq lebih menggambarkan pada bagaimana sisi ideal yang harus dimiliki oleh penganut agama Islam.

Dalam pengertian lebih sederhana, kepribadian dapat dilihat secara individu dan juga secara berkelompok. Secara individu ialah ciri khas yang dimiliki oleh individu baik sisi tingkah laku maupun pemikiran. Dengan demikian akan ada perbedaan ciri khas dari masing-masing muslim satu dengan muslim lainnya yang terlahir sebagai inividu khas, unik, dan sempurna. ${ }^{4}$

Kepribadian muslim unggul ialah Kepribadian yang mempunyai kesadaran diri dan posisi citra diri sendiri dalam rentang yang dimulai dari pembiasaan, peneladanan, pemahaman, penghayatan, dan penerapan serta pengamalan ibadah. Satu hal yang membedakan kerkait kepribadian didalam agama Islam dengan kajian di Barat yakni berkaitan dengan posisi substansi Ruhani. al Ghazali menyebut dengan istilah al-Ruh al-Jismiyyah, yaitu Ruh yang menjadikan manusia bergerak serta memberikan manusia rasa. Ruh inilah mampu memberikan cahaya sebagai penerang manusia untuk mempunyai daya untuk membedakan baik maupun buruk dari perilaku. ${ }^{5}$

Daya yang dimiliki manusia dalam bertingkah laku dipengaruhi emosi maupun kognisi yang terwujud dalam tingkah laku yang ditimbulkan, baik secara tingkah laku dalam berjalan, berpikir, perasaan, dan sebagainya. ${ }^{6}$ Daya tersebut saling berinteraksi satu sama lain, sedangkan kepribadian merupakan produk dari komponen daya yang berwujud tingkah laku. Kecenderungan manusia dalam memilih tingkah laku baik maupun buruk dipengaruhi oleh ruhaninya, ruh bersifat ketuhanan al-Lahutiyyah,

3 Duane Schultz, Theories of Personalit, Second Edition (California: Brooks/Cole Publishing Company Monterey, 1981)

4 Jalaludin, Teologi Pendidikan (Jakarta: Raja Grafindo Persada, 2001), hlm.172.

${ }^{5}$ Sayyid Muhammad ibn Muhammad al-Husaini al-Zubaidi, Ittihâf al-Sa'âdah al-Muttaqîn bi Syarh Ihyâ' 'Ulûm al-Dîn, Jilid VIII (Beirut: Dâr al-Kutub al-'Ilmiyyah, 1989), hlm. 370-371.

${ }^{6}$ Imam al-Ghazali, Tt. Kimiya' al-Sa'adah (Beirut: al-Maktabah al-Sa'biyah, tt), hIm. 27. 
mempunyai daya memberikan pancaran nur ilahi yang suci, dan dapat mengarahkan manusia slam meluruskan akal budi. ${ }^{7}$

Adapun kepribadian ulul albab menurut pandangan Muhaimin, berdasarkan hasil kajian terhadap istilah "Ulul Albab", terdapat 5 (lima) ciri utama karakter kepribadian, yaitu: (1) Selalu sadar akan kehadiran Tuhan disertai dengan kemampuan menggunakan potensi kalbu (dzikir), dan akal (pikir) sehingga sampai pada keyakinan adanya keagungan Allah swt dalam segala ciptaannya; (2) Tidak takut kepada siapapun kecuali kepada Allah swt, mampu membedakan dan memilih antara yang baik dan yang jelek; (3) Mementingkan kualitas hidup baik dalam keyakinan, ucapan maupun perbuatan, sabar dan tahan uji; (4) Bersungguh-sungguh dan kritis dalam menggali ilmu pengetahuan; (5) Bersedia menyampaikan ilmunya kepada masyarakat dan terpanggil hatinya untuk ikut memecahkan problem yang dihadapi masyarakat. ${ }^{8}$

Pendapat lain dari Imam Supyayogo bahwa Ulul Albab merupakan implementasi dari $d z i k r$, fikr dan amal saleh. Dengan mengimplementasikan hal tersebut mampu mengantarkan manusia menjadi unggul, sehat secara jasmani dan ruhani. Sebagai manusia yang unggul dari umumnya, selalu melakukan kegiatan dan pelayanan terbaik pada sesama "khair an nas anfa'uhum li annas. Orang yang memiliki pengetahuan luas, serta mampu melihat dan membaca fenomena alam dan sosial secara tepat. ${ }^{9}$

Senada dengan pendapat diatas, menurut Azis bahwa yang dimaksud dengan pribadi ulul albab adalah orang yang mempunyai empat ciri utama kepribadian diantaranya adalah, kedalaman spiritual, keagungan akhlak, keluasan ilmu, dan kematangan profesional. Hal ini berbeda dengan pendapat sebelumnya, secara teoritik dalam pengembangan alat ukur mengenai kepribadian ulul albab adalah: ${ }^{10}$

7 Lihat Muhammad Mahmûd Mahmûd, 'Ilm al-Nafs al-Ma'âshir fíDhaw'i alIslâm (Jeddah: Dâr al-Syurûq, 1984), hlm. 29-32. Syams al-Dîn ibn 'Abd Allâh Ibn Qayyim al-Jauziyyah, al-Rûh fi al-Kalâm 'alâ 'Arwâh al-'Amwât wa al-'Ahwâ bi al-Dalîl min al-Kitâb wa al-Sunnah wa al-âtsâr wa al-Aqwâl al-'Ulamâ' (Beirut: Dâr al-Fikr, 1992), hlm. 212-214.

8 Muhaimin, "Penyiapan Ulul Albab, Pendidikan Alternatif masa Depan”, el Hikmah, Jurnal Pendidikan Fakultas Tarbiyah, Vol.1 No.1, 2003, hlm. 20

${ }^{9}$ Imam Suprayogo, Paradigma Pengembangan Keilmuan di Perguruan Tinggi: Konsep Pendidikan Tinggi yang dikembangkan UIN Malang (Malang: UIN Malang Press, 2005), hlm. 30.

10 Rahmat Azis, Ulul Albab Citra Diri dan Religiusiras Mahasiswa di Era Globalisasi (Malang: UIN Maliki Press, 2012), hlm. 55-59. 
1. Kedalaman spiritual, yaitu kemampuan individu dalam memaknai kehidupan dan berperilaku yang didasari dengan adanya semangat spiritual. Kemampuan ini dicirikan dengan adanya kesadaran terhadap kehadiran Allah, kemampuan untuk mengagumi ciptaan Allah, dan adanya rasa takut hanya oleh Allah.

2. Keagungan akhlak, yaitu kemampuan individu untuk berperilaku mulia sesuai dengan ajaran Islam sehingga perilaku tersebut menjadi ciri dari kepribadiannya. Kemampuan ini dicirikan dengan adanya kemampuan untuk meningkatkan kualitas hidup baik berupa keyakinan, lisan, maupun perbuatan, dan kemampuan untuk bersabar dalam menghadapi cobaan, dan kemampuan membedakan yang baik dan yang buruk.

3. Keluasan ilmu, yaitu kualitas seseorang yang dicirikan dengan kepintaran dan kecerdikan dalam menyelesaikan masalah sesuai dengan bidang keahliannya. Kemampuan ini dicirikan dengan sikap bersungguh-sungguh dalam mencari ilmu, kemampuan untuk selalu menggunakan potensi akal fikiran, dan kemampuan untuk selalu menggunakan potensi kalbu (perasaan).

4. Kematangan profesional, yaitu kemampuan seseorang untuk bekerja dan berperilaku sebagai seorang profesional dibidangnya. Kemampuan ini dicirikan dengan adanya kebiasaan untuk bertindak sesuai dengan ilmu, kesediaan untuk menyampaikan ilmu, kesediaan berperan serta dalam memecahkan masalah umat.

\section{Telaah Generasi dan Problematika Millenial}

Berbicara mengenai jargon generasi milenial ialah pembedaan berdasarkan tahun kelahiran, kebiasaan, gaya hidup, pola berbicara serta cara memperoleh dan mengolah informasi, sikap dalam mengambil keputusan. Menurut Manheim, ${ }^{11}$ generasi merupakan sekelompok dari individu-individu yang memiliki kesamaan dalam rentang usia, serta pengalaman dari peristiwa dalam periode yang sama. ${ }^{12}$ Lebih lanjut individu yang terkelompok dalam satu generasi memiliki rentang waktu kelahiran 20 tahun. ${ }^{13}$

11 Manheim dalam Pauline Pantauw, "Mendidik Generasi Z", www.beyondchildhood.com, pada tanggal 11 Januari 2018 pukul 08.00

12 Hari wibawanto, "Generasi z dan pembelajaran di pendidikan tinggi". http://event.elearning.itb.ac.id, pada tanggal 20 Januari 2018 pukul 21.30

13 Lebih lengkap lihat Manheim, "The Problem of Generations", Essays on the Sociology of Knowledge, 24(19), 276-322-24. 
Kesamaan seperti pendapat Manheim, William Strauss dan Neil Howe mendefinisikan generasi ialah kesamaan rentangan waktu kelahiran dan memilliki kesamaan secara historis. Sama dengan Manheim, Strauss dan Howe berpandangan bahwa rentangan waktu antar generasi dua puluh tahun. Panjang fase dari masa anak-anak, dewasa, dan usia tua. ${ }^{14}$ Dapat disimpulkan bahwa kriteria yang dimiliki generasi antara lain, usia dalam rentang waktu yang sama. Atau memiliki trend yang sama dalam sosial, kepercayaan, dan perilaku yang sama, keanggotaan periode yang sama atau memiliki kelompok yang berbeda dari generasi lainnya. Lebih jelasnya seperti pada tabel 1. berikut ini;

Tabel 1. Pengelompokan Generasi (Howe dan Strauss) ${ }^{15}$

\begin{tabular}{|c|c|c|}
\hline GENERASI & KELAHIRAN & PERISTIWA DAN KARAKTERISTIK \\
\hline $\begin{array}{l}\text { INTERBELLUM } \\
\text { GENERATION }\end{array}$ & 1901-1924 & $\begin{array}{l}\text { Setelah perang dunia pertama, G.I. Bill yaitu } \\
\text { subsidi besar yang diberikan pemerintah } \\
\text { kepada veteran yang kembali dari perang } \\
\text { dunia mebuat generasi G.I cukup dimanja. }\end{array}$ \\
\hline $\begin{array}{c}\text { SILENT } \\
\text { GENERATION }\end{array}$ & 1925-1942 & $\begin{array}{l}\text { Menjalani masa kecil yang diwarnai krisis } \\
\text { seperti Great Depression dan perang dumia } \\
\text { II, bahkan kejadian Pearl Harbour dan } D- \\
\text { Day, generasi ini termasuk generasi yang } \\
\text { diam. }\end{array}$ \\
\hline $\begin{array}{c}\text { BOOM } \\
\text { GENERATION }\end{array}$ & 1943-1960 & $\begin{array}{l}\text { Angka kelahiran meningkat drastis karena } \\
\text { kemakmuran saat itu sehingga mereka } \\
\text { disebut Baby Boomers. Hal ini terjadi } \\
\text { karena perang dunia II telah berakir di } \\
\text { mana rakyat AS mengalami opstimisme } \\
\text { pasca perang }\end{array}$ \\
\hline GENERAT & 1961-1981 & $\begin{array}{l}\text { Consciousness Revolution di mana sedang } \\
\text { terjadi pemberontakan seperti Tax Revolt } \\
\text { sehingga kesejahteraan anak bukanlah } \\
\text { prioritas sosial utama. Seks lebih eksplisit, } \\
\text { angka perceraian tinggi }\end{array}$ \\
\hline MILE & 1982-2004 & 'Goal 2000' dan 'No Child Left Behind' \\
\hline
\end{tabular}

14 Reynaldi Satrio Nugroho, "Pengantar Teori Generasi Strauss-Howe", Majalah Ganesha, Kelompok Studi Sejarah, Ekonomi dan Politik, ITB Bandung 9 Februari 2016, lihat juga, Howe, N. dan Stauss W, Generation: The History of America's Future. 1584 to 2069. (New York: William Morrow Paperback, tt).

${ }^{15}$ Reynaldi Satrio Nugroho, "Pengantar Teori Generasi Strauss-How" ... hlm.2 

Millennial dibesarkan dalam kondisi baik walaupun mereka hadir pada masa perang budaya.

Berbeda dengan pendapat Strauss dan Howe, yang mengelompokkan generasi berdasarkan kondisi trend yang sama dalam sosial, kepercayaan dan perilaku yang sama, keanggotaan periode yang sama atau memiliki kelompok yang berbeda dari generasi lainnya. Teori generasi tersebut hanya berbasis pada kondisional sejarah di Amerika Serikat saja. Sehingga perlu adanya pengelompokkan generasi yang bisa diterima disemua tempat, bukan hanya di Amerika saja. Salah satu hasil penelitian yang fokus dalam mengambil sampel mulai tahun 1950an sampai tahun 2000an awal, terdapat 3 berbedaan karakteristik dari 3 generasi. Generasi Baby Boomers, Generasi X dan Y Milenial, sebagaimana hasil dari penelitian yang pernah dilakukan oleh Lancaster dan Stillman pada tabel 2. berikut:

Tabel 2. Perbedaan Generasi (Lancaster dan Stillman) ${ }^{16}$

\begin{tabular}{|c|c|c|c|}
\hline FAKTOR & $\begin{array}{l}\text { BABY } \\
\text { BOOMERS }\end{array}$ & GENERATION X & $\begin{array}{l}\text { MILLENNIAL } \\
\text { GENERATION Y }\end{array}$ \\
\hline ATTITUDE & Optimis & Skeptis & Realistis \\
\hline OVERVIEW & $\begin{array}{l}\text { Generasi ini } \\
\text { percaya pada } \\
\text { adanya peluang, } \\
\text { dan seringkali } \\
\text { terlalu idealis } \\
\text { untuk membuat } \\
\text { perubahan } \\
\text { positif didunia. } \\
\text { Mereka juga } \\
\text { kompetitif dan } \\
\text { mencari cara } \\
\text { untuk } \\
\text { melakukan }\end{array}$ & $\begin{array}{l}\text { Generasi yang } \\
\text { tetutup, sangat } \\
\text { independen dan } \\
\text { punya potens, tidak } \\
\text { bergantung pada } \\
\text { orang lain untuk } \\
\text { menolong mereka }\end{array}$ & $\begin{array}{l}\text { Sangat } \\
\text { menghargai } \\
\text { perbedaan, } \\
\text { lebih memilih } \\
\text { bekerja sama } \\
\text { daripada } \\
\text { menerima } \\
\text { perintah dan } \\
\text { sangat } \\
\text { pragmatis kerika } \\
\text { memecahkan } \\
\text { persoalan }\end{array}$ \\
\hline
\end{tabular}

${ }^{16}$ Yanuar Surya, "Teori Perbedaan Generasi", Putra Among Makarti, Vol.9 No.18, Desember 2016, HIm. 128, Lancaster, L. C. and Stillman, D. When Generations Collide. Who They Are. Why They Clash. How to Solve the Generational Puzzle at Work (New York: Collins Business, 2002). 


\begin{tabular}{|c|c|c|c|}
\hline & $\begin{array}{l}\text { perubahan } \\
\text { mulai dari } \\
\text { sistem yang } \\
\text { sudah ada. }\end{array}$ & & \\
\hline $\begin{array}{l}\text { WORK } \\
\text { HABITS }\end{array}$ & $\begin{array}{l}\text { Punya rasa } \\
\text { optimis yang } \\
\text { tinggi, pekerja } \\
\text { keras yang } \\
\text { menginginkan } \\
\text { penghargaan } \\
\text { secara personal, } \\
\text { percaya pada } \\
\text { perubahan dan } \\
\text { perkembangan } \\
\text { diri sendiri }\end{array}$ & $\begin{array}{l}\text { Menyadari adanya } \\
\text { keragaman dan } \\
\text { berpikir global, } \\
\text { seimbang antara } \\
\text { pekerjaan dengan } \\
\text { kehidupan, bersifat } \\
\text { informal, } \\
\text { mengandalkan diri } \\
\text { sendiri, praktis } \\
\text { dalam bekerja, ingin } \\
\text { bersenang-senang } \\
\text { dalam bekerja, } \\
\text { senang bekerja } \\
\text { dengan teknologi } \\
\text { baru. }\end{array}$ & $\begin{array}{l}\text { Memilih rasa } \\
\text { optimis yang } \\
\text { tinggi, fokus } \\
\text { pada prestasi, } \\
\text { percaya diri, } \\
\text { percaya pada } \\
\text { nilai-nilai moral } \\
\text { dan sosial, } \\
\text { menghargai } \\
\text { adanya } \\
\text { keragaman }\end{array}$ \\
\hline
\end{tabular}

Dari penjelasan diatas menurut para ahli, dapat diketahui bahwa Baby Boomers ialah generasi yang lahir pasca perang dunia kedua tepatnya tahun 1946 hingga 1960. Akibat dari adanya perang, angka kelahiran pada masa Baby Boomers sangat tinggi sebagai imbas dari banyaknya orang meninggal akibat perang.

Sedangkan Generasi X, ialah mereka yang terlahir pada tahun 1961 hingga 1981. Awal dari perkembangan teknologi informasi dan komunikasi seperti PC (personal komputer), televisi, video games, dan internet. Generasi ini memiliki ciri mampu beradaptasi, mampu menerima perubahan, memiliki karakter mandiri dan loyal.

Adapun Generasi Milenial ialah generasi yang terlahir antara tahun 1982 hingga 2004, generasi ini hidup dimasa percepatan perkembangan teknologi informasi dan komunikasi digital. Karakter yang dimiliki generasi ini ialah lebih berpikiran terbuka, reaktif terhadap perubahan yang terjadi dilingkunganya.

Dari karakteristik yang dideskripsikan di atas, bahwa generasi millenial $Y$ memiliki banyak kelebihan dibandingkan generasi pendahulunya. Dilain sisi juga mereka tidak lepas dari kekurangan. Terkait permasalahan yang banyak dihadapi oleh generasi millenial. Menurut Bambang Suryadi, berdasarkan 
data problem yang banyak dihadapi oleh generasi millenial, melalui hasil riset dari 176 responden diperoleh sebagaimana tabel 3. berikut.

\section{Tabel 3. Masalah Gen Milenial Bambang Suryadi ${ }^{17}$}

\begin{tabular}{clc} 
No & \multicolumn{1}{c}{ Karakteristik } & F \& \% \\
$\mathbf{1}$ & Adiksi gadget & $146(80 \%)$ \\
$\mathbf{2}$ & Tidak fokus belajar & $124(78 \%)$ \\
$\mathbf{3}$ & Emosi mudah terganggu & $103(70 \%)$ \\
$\mathbf{4}$ & Pornografi & $61(69 \%)$ \\
$\mathbf{5}$ & Pergaulan bebas & $52(66 \%)$ \\
$\mathbf{6}$ & Lain-lain & $16(64 \%)$
\end{tabular}

Berdasarkan riset generasi milenial yang dilakukan oleh Bambang Suryadi, permasalahan serius dihadapi oleh generasi milenial adalah terkait dengan persoalan teknologi komunikasi digital, persoalan tersebut antara lain berhubungan dengan adiksi gadget, tidak fokus belajar, dan mudah emosi. Tidak hanya itu saja, permasalahan lain yang dihadapi oleh generasi milenial yakni terkait pornografi dan pergaulan bebas. Sedangkan permasalahan lainnya antara lain masalah keluarga, keuangan, pribadi dan lain sebagainya.

\section{Bingkai Kepribadian Ulul Albab Generasi Milenial}

Menurut Suprayogo ukuran keberhasilan dari pendidikan Ulul Albab dianggap tercapai ketika pribadi yang terbentuk dalam proses pendidikan memiliki kualitas sebagai berikut: 1) Mempunyai ilmu pengetahuan yang luas; 2) Mempunyai penglihatan yanag tajam; 3) Bercorak cerdas; 4) Berhati lembut; 5) Bersemangat juang tinggi karena Allah sebagai pengejawantahan amal shaleh. Selanjutnya dikatakan bahwa pribadi ulul albab meyakini adanya kehidupan jasmani dan ruhani, dunia dan akhirat. Kedua dimensi kehidupan tersebut harus memperoleh perhatian yang seimbang dan tidak dibenarkan hanya memprioritaskan salah satunya. Keberuntungan dunia harus berdampak positif pada kehidupan akhirat, demikian juga sebaliknya. Hal ini didasari ajaran Rasulullah yang mengharuskan umat Islam untuk mencari kehidupan dunia seolah-olah akan hidup selamanya, dan mencari kehidupan akhirat seolah-olah kematian sudah di depan mata. Untuk mencapai tujuan tersebut maka pendidikan harus mampu mengembangkan dzikir, fikir, dan amal shaleh.

${ }^{17}$ Bambang Suryadi, "Generasi Y: Karakteristik, Masalah dan Peran Konselor", (Makalah Workshop International MALINDO 4 di Bali, 22-23 Mei 2015) 
Sedangkan problematika yang dihadapi oleh generasi millenial berdasarkan kajian yang dilakukan Bambang suryadi antara lain: Adiksi gadget, tidak fokus belajar, emosi mudah terganggu, pornografi, pergaulan bebas, sebagaimana uraian gambar 1. dibawah ini.

\section{Gambar 1. Problem Generasi Milenial}

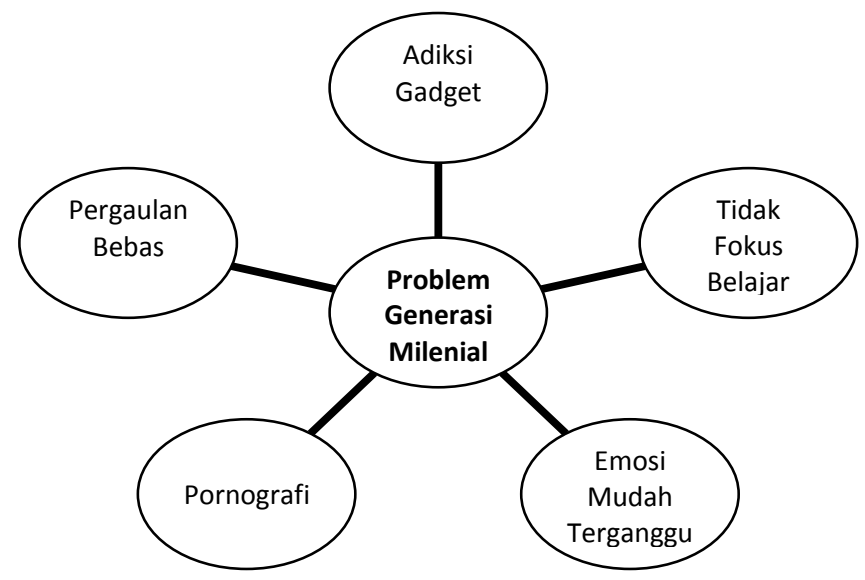

1. Adiksi gadget, ketergantungan yang menggambarkan penggunaan secara berlebihan, mengakibatkan lupa waktu, mengganggu konsentrasi belajar, membuat penurunan kemampuan sosialisasi. ${ }^{18}$

2. Tidak fokus belajar, penyebab penggunaaan teknologi gadget game, media sosial berlebihan sehingga berakibat kecanduan dan sulit untuk fokus belajar. Delirium Dementia, penurunan intelektual karena kekacauan mental. ${ }^{19}$

3. Emosi mudah terganggu, kaum milenial yang kesepian lebih rentan mengalami depresi dan gangguan kecemasan secara emosi, seperti kesedihan, kecemasan, dan perasaan takut. Beberapa penyebabnya sering dikaitkan dengan penggunaan media sosial serta kemajuan teknologi lainnya. ${ }^{20}$

4. Pornografi, pemaparan pornografi pada remaja mempunyai skala nasional. Penelitian Komisi Nasional Perlindungan Anak, tahun 2007,

18 Soetjipto, Helly P. "Pengujian Validitas Konstruk Kriteria Kecanduan Internet", Universitas Gadjah Mada, Volume 32, No. 32, No. 2, hlm. 74-91.

19 Abdul Mujib, Kepribadian dalam Psikologi Islam (Jakarta: Rajawali Pers, 2006), hlm. 370.

20 Tuty Ocktaviany (Ed), "Selain Gangguan Kecemasan, Kaum Milenial Lebih Rentan Kena Depresi. 
pada 4500 remaja di 12 kota besar di Indonesia mengungkapkan bahwa 97 persen remaja tersebut pernah menonton film porno. ${ }^{21}$ Penelitian yang dilakukan End Child Prostitution, Child Pornography and Trafficking of Children for Sexual Purposes (Ecpat) malah menemukan Indonesia merupakan negara terbesar kedua pengakses konten pornografi di dunia maya.

5. Pergaulan bebas, degradasi secara moral terkait kenakalan remaja dalam masyarakat, seperti perkelahian massal, penggunaan obat terlarang, dan berbagai kasus dekadensi moral lainnya. Sehingga sulit melakukan penyesuaian diri karena perilakunya bertentangan dengan peri kemanusiaan. ${ }^{22}$

Kepribadian seseorang terbentuk melalui internalisasi berbagai nilai yang diyakini dan digunakan sebagai landasan untuk cara pandang, berpikir, bersikap, dan bertindak. Pola bingkai internalisasi kepribadian ulul albab terdiri atas sikap atau perilaku yang mencerminkan kedalaman spiritual, keagungan akhlak, keluasan ilmu, dan kematangan profesional. Artinya, internalisasi kepribadian hanya dapat dilakukan dalam suatu proses pendidikan yang tidak melepaskan diri dari nilai agama, lingkungan sosial, budaya masyarakat, dan budaya bangsa sebagaimana pada tabel bingkai internalisasi kepribadian ulul albab generasi milenial pada gambar 3.

Gambar 2. Internalisasi Nilai Ulul Albab

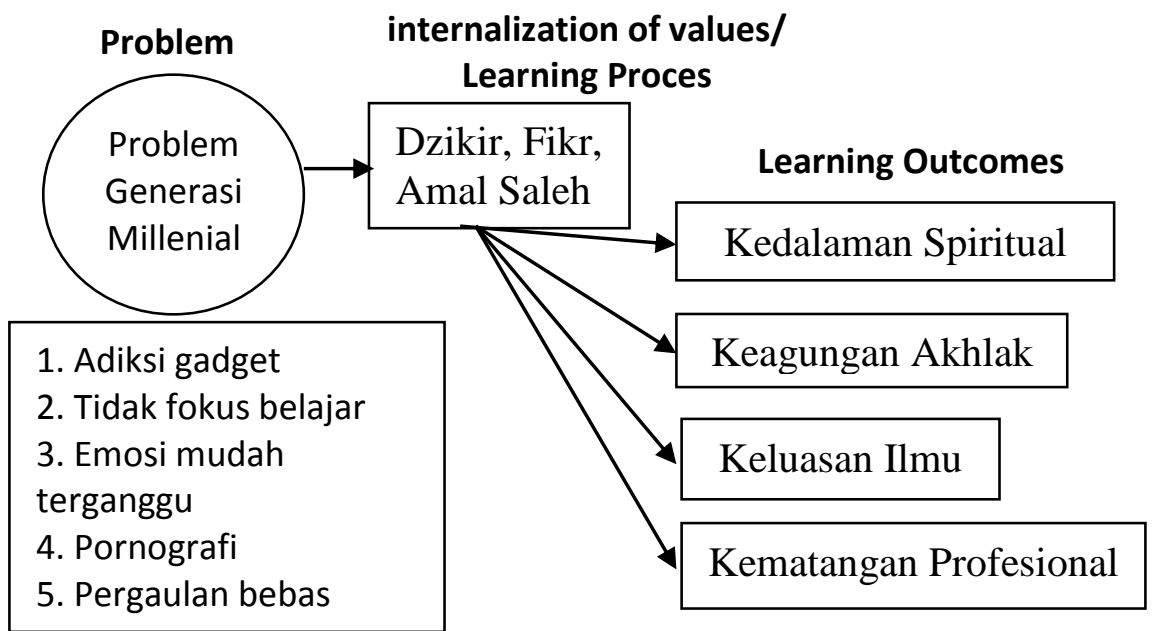

21 "Pornografi rusak jaringan otak", www.gatra.com, pada tanggal 2 Maret 2009 pukul 13.00.

${ }^{22}$ Abdul Mujib, Kepribadian dalam Psikologi Islam.., hlm. 372. 
Sebagaimana pada gambar 3. diatas, bahwa generasi millenial berbeda dengan generasi sebelumnya. Generasi milenial tidak bisa lepas dengan teknologi. Salah satu ciri mereka susah untuk bersosialisasi secara langsung, sosialisasi mereka dibatasi oleh media sosial. Generasi millenial memiliki kemudahan mengakses segala informasi tanpa batas, inilah yang menjadi pemicu berbagai problem generasi milenial.

Internalisasi nilai melalui proses pendidikan dan pembalajaran, bukan berarti mendobrak dan menjauhkan generasi milenial dari karakteristik zaman yang dimilikinya. Mereka tidak dijauhkan dari dunianya yang sadar akan teknologi sebagai kebutuhan berinteraksi dan menggali berbagai informasi. Internalisasi nilai dimungkinkan agar generasi milenial memiliki fondasi keagamaan yang kokoh, sehingga dapat memberikan nuansa arah positif dan penggunaan kemudahan akses teknologi informasi dan komunikasi sebagai kebutuhan, yakni melalui internalisasi Dzikir, Fikr, Amal Saleh pada tabel 4 . berikut. $^{23}$

Tabel 4. Internalisasi Dzikir, Fikir, Amal Saleh

\begin{tabular}{ll}
\hline Dzikir & - Sholat berjamaah: wajib dan sunat \\
& - Khatmul Qur'an \\
& - Puasa wajib/sunat \\
& - Memperbanyak kalimah thoyibah, tasbih, takbir, \\
& tahmid, shalawat \\
\hline Fikr & - Penajaman nalar dan pikir tentang perilaku \\
& makrokosmos dan \\
& mikrokosmos; \\
& interaksi social \\
\hline Amal Saleh & Memberi manfaat kepada dirinya dan kepada banyak \\
& orang
\end{tabular}

Inti dari internalisasi nilai ulul albab dzikir, fikir, amal saleh ialah sebagai pembinaan secara ruhani atau kepribadian yang sesuai dengan praktik hidup Islami. Melalui bimbingan, pengajaran, yang memiliki kualitas sebagai muslim yang ulul albab. Secara outcomes learning memiliki pandangan hidup, sikap hidup, keterampilan hidup berperspektif islami. Yaitu memiliki kedalaman spiritual, keagungan akhlak, keluasan ilmu dan kematangan profesional sebagaimana berikut ini. ${ }^{24}$

1. Kedalaman Spiritual, Menghadirkan Allah dan selalu merasa diawasi oleh Allah dalam setiap aktifitasnya, menjauhkan dirik dari perbagai hal

${ }^{23}$ Imam Suprayogo, Tarbiyatu ulil Albab: Dzikr, Fikr, dan Amal Saleh, (Malang: Universitas Islam Indonesia-Sudan, 2002)

${ }^{24}$ Rahmat Azis, Ulul Albab Citra Diri dan Religiusiras Mahasiswa..., hlm. 59. 
yang merugikan dan dilarang oleh agama seperti pornografi dan pergaulan bebas.

2. Keagungan Akhlak, Mampu membedakan hal yang baik dan buruk, berusaha meningkatkan kualitas hidup dengan berinteraksi secara sosial yang baik.

3. Keluasan Ilmu, Bersungguh-sungguh dan fokus dalam belajar serta mengekplore berbagai pengetahuan yang banyak demi kemaslahatan umat.

4. Kematangan Profesional, Kesadaran menyampaikan ilmu yang diperoleh serta memiliki tanggung jawab untuk memecahkan berbagai problematika di masyarakat.

\section{Penutup}

Terdapat dua ciri khas khusus karakter kepribadian ulul albab, antara lain; Pertama, mampu mengantarkan manusia berbudaya unggul, Kedua, sehat secara jasmani serta ruhani. Sedangkan ciri manusia yang unggul adalah selalu melakukan kebajikan pada sesama. Indikatornya manusia unggul yakni memiliki semangat mendapatkan pengetahuan luas, dan mampu melihat dan membaca fenomena alam dan sosial secara tepat.

Berdasarkan rentangan periodesasi waktu dan karakteristik. Generasi millenial secara perilaku dan psikografis lahir di era teknologi digital intenet. Memiliki perilaku adaptif sangat cepat terhadap segala sesuatu yang bernuansa digital. Ciri lainnya memiliki banyak kelebihan menyerap informasi lebih banyak. Sedangkan problem yang dihadapi generasi millenial diantaranya adalah Adiksi gadget, tidak fokus pada belajar, emosi mudah terganggu, pornografi, pergaulan bebas.

Konseptual bingkai kepribadian ulul albab untuk menyelesaikan problematika generasi millenial ialah melalui internalisasi nilai kepribadian ulul albab. Secara learning proces melalui pengamalan dzikr, fikr, dan amal saleh. Sehingga secara luaran bukan memisahkan generasi millenial dengan keunikannya memiliki kelebihan dalam penggunaan teknologi digital, tetapi sebagai benteng untuk tetap memiliki karakter sesuai dengan norma dan etika Islami. Secara learning proses, melalui: a) Dzikir, b). Fikir, c). Amal Saleh. Sehingga dapat diharapkan menghasilkan luaran memiliki ciri keunggulan secara: a). Spiritual, b). akhlak, c). Keilmuan, d). Profesional.

\section{Dartar Rujukan}

Ali, Hasanudin, "Generasi Millennial Indonesia: Tantangan dan Peluang Pemuda Indonesia", http://alvara-strategic.com, pada tanggal 30 desember 2017 jam 07.00. 
Hari wibawanto, "Generasi z dan pembelajaran di pendidikan tinggi". http://event.elearning.itb.ac.id, pada tanggal 20 Januari 2018 pukul 21.30.

Jalaludin, Teologi Pendidikan, Jakarta: Raja Grafindo Persada, 2001.

Sayyid Muhammad ibn Muhammad al-Husaini al-Zubaidi, Ittihâf al-Sa'âdah al-Muttaqîn bi Syarh Ihyâ' 'Ulûm al-Dîn, Jilid VIII, Beirut: Dâr al-Kutub al-'Ilmiyyah, 1989.

Schultz, Duane, Theories of Personalit, Second Edition, California: Brooks/Cole Publishing Company Monterey, 1981.

Syams al-Dîn ibn 'Abd Allâh Ibn Qayyim al-Jauziyyah, al-Rûh fi al-Kalâm 'alâ 'Arwâh al-'Amwât wa al-'Ahwâ bi al-Dalîl min al-Kitâb wa al-Sunnah wa al-âtsâr wa al-Aqwâl al-'Ulamâ', Beirut: Dâr al-Fikr, 1992.

Imam al-Ghazali, Tt. Kimiya' al-Sa'adah, Beirut: al-Maktabah al-Sa'biyah, tt.

Lancaster, L. C. and Stillman, D. When Generations Collide. Who They Are. Why They Clash. How to Solve the Generational Puzzle at Work, New York: Collins Business, 2002.

Mahmûd, Muhammad, 'Ilm al-Nafs al-Ma'âshir fíDhaw'i al-Islâm, Jeddah: Dâr al-Syurûq, 1984.

Manheim, "The Problem of Generations", Essays on the Sociology of Knowledge, 24(19), 276-322-24.

Muhaimin, "Penyiapan Ulul Albab, Pendidikan Alternatif masa Depan”, el Hikmah, Jurnal Pendidikan Fakultas Tarbiyah, Vol.1 No.1, 2003.

Mujib, Abdul, Kepribadian dalam Psikologi Islam, Jakarta: Rajawali Pers, 2006.

Naisbitt, John. Et. All. High Tech High Touch, Jakarta: Pustaka Mizan, 2002.

Ocktaviany, Tuty (Ed), "Selain Gangguan Kecemasan, Kaum Milenial Lebih Rentan Kena Depresi", www.inews.id, pada tanggal 21 Februari 2018 pukul 20.00.

Pauline Pantauw, "Mendidik Generasi Z", www.beyondchildhood.com, pada tanggal 11 Januari 2018 pukul 08.00.

"Pornografi rusak jaringan otak", www.gatra.com, pada tanggal 2 Maret 2009 pukul 13.00 . 
Rahmat Azis, Ulul Albab Citra Diri dan Religiusiras Mahasiswa di Era Globalisasi, Malang: UIN Maliki Press, 2012.

Soetjipto, Helly P. "Pengujian Validitas Konstruk Kriteria Kecanduan Internet", Universitas Gadjah Mada, Volume 32, No. 32, No. 2, hlm. 74-91.

Suprayogo, Imam, Paradigma Pengembangan Keilmuan di Perguruan Tinggi: Konsep Pendidikan Tinggi yang dikembangkan UIN Malang, Malang: UIN Malang Press, 2005.

Suprayogo, Imam, Tarbiyatu ulil Albab: Dzikr, Fikr, dan Amal Saleh, Malang: Universitas Islam Indonesia-Sudan, 2002.

Suryadi, Bambang, "Generasi Y: Karakteristik, Masalah dan Peran Konselor", (Makalah Workshop International MALINDO 4 di Bali, 22-23 Mei 2015).

Reynaldi Satrio Nugroho, "Pengantar Teori Generasi Strauss-Howe", Majalah Ganesha, Kelompok Studi Sejarah, Ekonomi dan Politik, ITB Bandung 9 Februari 2016, lihat juga, Howe, N. dan Stauss W, Generation: The History of America's Future. 1584 to 2069. (New York: William Morrow Paperback, $\mathrm{tt}$ ).

Yanuar Surya, "Teori Perbedaan Generasi", Putra Among Makarti, Vol.9 No.18, Desember 2016.

Zuhal, Visi Iptek Memasuki Milenium III, Jakarta: Universitas Pendidikan Indonesi Pers, 2000. 